\title{
Research on Training Path of Rural E-commerce Talents in Hubei
}

\author{
Yitang Zeng ${ }^{\mathrm{a}}$, Zhongyuan Ma, Yachi Lu, Mengxiao Wang and Li Li* \\ Wuhan Donghu University, China \\ ayitangzeng@qq.com \\ *Corresponding author
}

Keywords: Rural E-commerce; Talents; Training path.

\begin{abstract}
There are some problems in Hubei rural e-commerce talents, such as unbalanced supply and demand, difficult introduction, inadequate training ability, backward rural conditions, imperfect related policies and weak funds. This paper puts forward the corresponding training path of Hubei rural e-commerce talents from the aspects of improving the training ability, enhancing the support and innovating the training mode. It offers advice to train excellent and suitable rural e-commerce talents, so as to promote better and faster development of rural e-commerce.
\end{abstract}

\section{Introduction}

In the era of "Internet +", rural e-commerce continues to develop, and the comprehensive demand for talents in rural e-commerce enterprises is also improving. Hubei provincial government has been encouraging migrant workers and college students to return home and start their own businesses, promoting agricultural technicians with Internet knowledge to help rural e-commerce development. However, due to the large gap between rural economic development and living, education, medical care level and the city, there is a lack of resources to attract talent, return home to start their own businesses, and the city. The number of city assists is increasing slowly, and personnel training is also facing great difficulties.

Sun Wei (2013) believes that attention should be paid to the cultivation of students' operability, and schools and enterprises should cooperate strategically to build practical teaching bases with local rural characteristics [1]. Cheng Lili (2014) pointed out that the government should pay attention to the needs of e-commerce talents in rural areas targeted research, combined with the different characteristics of the region, using a multi-dimensional nested training path [2]. Lai Lingling and He Xiaofeng (2016) believe that to determine the training path from two aspects of technical personnel and entrepreneurial talent, we should focus on training students'e-commerce technology and e-commerce operation ability [3]. Era (2016) believes that we should focus on giving full play to the advantages of colleges and universities, and invite experts and scholars in agriculture, e-commerce, marketing and computer science to make teaching plans, starting from the comprehensive ability and potential development of students. In this way, we can not only adapt to the teaching requirements of schools, but also cultivate e e-commerce talents suitable for rural development, and promote local teaching development [4]. Ren Xiaocong, and Jun (2017) pointed out that government departments at all levels should also strengthen the training of relevant personnel, and strive to quickly cultivate a large number of knowledge and skills of high-quality rural e-commerce supervision personnel[5].

\section{Demand for E-commerce Talents in Rural Areas of Hubei}

Hubei rural e-commerce enterprises have a large talent gap and a high rate of brain drain. At the same time, the development of e-commerce in rural areas of Hubei Province is unbalanced, and there is a great demand for rural e-commerce talents in remote areas. In order to promote the better and faster development of rural e-commerce in Hubei Province, it is urgent to need a group of comprehensive talents who have a rich understanding of agricultural products and are familiar with 
e-commerce technology.

The demand for skilled talents. Technical personnel with a certain understanding of the relevant technologies of e-commerce, such as proficient in programming, code, art and other technical software.

The demand for business oriented talents. These talents need to understand modern rural business activities, have e-commerce business experience, have a high sensitivity to marketing strategies, market demand.

The demand for strategic talents. It has high sensitivity and clear thinking on the future development trend of rural e-commerce, and has strategic talents with forward-looking thinking.

Demand for rural electricity regulatory personnel. Our province is in urgent need of a group of high-quality rural electric business supervision talents with knowledge and skills. They must have network knowledge, rural e-commerce supervision knowledge, grasp the law enforcement means and skills of rural e-commerce supervision.

\section{Training of Rural E-commerce Talents in Hubei}

Lack of systematic personnel training plan. The Hubei provincial government lacks specific plans for the training of rural e-commerce talents. In the process of implementing e-commerce personnel training, it is superficial, and the effect of training comprehensive rural e-commerce personnel is not good.

The existing talents can not adapt to the needs of social development. Most universities in Hubei have set up e-commerce related specialties such as logistics, marketing and marketing since 2013. However, in terms of rural electricity providers, there is still a big shortage of school curriculum design.

The training mode is backward. The methods of cultivating rural e-commerce talents in Colleges and universities are not targeted and practical, and the popularization of e-commerce remains on the surface of knowledge.

\section{Problems and Reasons of E-commerce Talents in Rural Areas of Hubei}

\subsection{Problems of Rural e-commerce talents in Hubei}

\subsubsection{Imbalance between supply and demand}

At present, Hubei Province rural e-commerce related enterprise talent gap is large, most enterprises are new enterprises, resulting in more jobs, fewer people. In the demand for talents in enterprises, the most shortage of technical and business-oriented talents, and these two types of talents need long working experience accumulation. There is a buffer period in the training of e-commerce talents, which leads to a large demand for talents and a large gap of talents.

\subsubsection{Talent introduction difficulty}

The rural areas in Hubei Province are facing tough conditions and unbalanced opportunities for urban and rural development. It is difficult for talented people to obtain preferential treatment in rural areas. At the same time, there are few rural jobs and few opportunities for development. Rural young and middle-aged people mainly go out to work, study and start their own businesses. Most of them choose to stay in the city for development because they want to go home after graduation.

\subsubsection{Insufficient training ability}

The government has no standardized training base, no perfect network infrastructure for rural e-commerce, lack of local training teachers. Colleges and universities in rural e-commerce personnel courses are inadequate, in the process of training students, biased knowledge education, lack of practical education. Although some schools carry out school enterprise cooperation, there are few opportunities for students to go deep into enterprise practice. 


\subsubsection{Serious brain drain}

The development of e-commerce is fast and competition is relatively fierce. Although some young people in rural areas have been trained to engage in e-commerce, rural conditions are relatively backward, and there is limited room for rural workers to improve. Meanwhile, it is difficult to work in rural e-commerce for a short time, and brain drain is a serious phenomenon.

\subsection{Reasons of Rural e-commerce talents in Hubei}

\subsection{1 backward rural conditions}

According to the survey, the main reason why young people do not want to go to rural areas to engage in e-commerce work is the huge gap between urban and rural areas. Although the urban population is increasing, the competition for jobs is becoming more and more fierce, life is full of hardships, but the city provides people with a rich and convenient life. Despite the government's policy support for the development of rural areas, there are still some problems in the development of rural areas, such as weak information foundation, imperfect logistics and other infrastructure construction, rural e-commerce environment can not be improved in a short time [6].

\subsubsection{Related policies are not perfect}

The government's policy guarantee is not perfect enough, the preferential policies to encourage rural entrepreneurship are few, and the inclination is not enough. At the same time, there are few policies and regulations to cultivate rural e-commerce talents, and the investment in e-commerce education in rural areas is insufficient. On the other hand, the social security and welfare benefits provided by the local government can not attract talented people to work in rural areas.

\subsubsection{Weak funds}

Government funds are limited, and there is a lack of funds for the construction of rural infrastructure. The government's financial support for training talents is insufficient, and the proposed planning and training programs are difficult to implement. It is difficult to attract strong rural e-commerce talents because of the insufficient social security and remuneration for rural e-commerce. In the process of training rural e-commerce talents, schools lack funds, computer and other basic equipment, and hold fewer expert seminars. Especially in organizing practical activities, a large amount of money is needed to support students to study in enterprises and rural areas [7].

\section{Training Path of Rural E-commerce Talents in Hubei}

\subsection{Improve training ability}

In order to cultivate talents of rural electric business, Hubei province must improve its training ability. Starting from the current situation of rural areas and the development of e-commerce, we should think more about the education model, so as to cultivate talents with a goal and direction. We should carry out the training of talents from the government, colleges and universities, optimize the training program, pay attention to the integration of agricultural knowledge, pay attention to practical teaching and strengthen the construction of teaching staff [8]. What kind of talents do we need to make clear in the process of developing rural e-commerce? According to the situation of talent demand, this paper puts forward the training methods of rural e-commerce talents, so as to improve the training ability.

\subsubsection{Reasonable planning and training plan}

Colleges and universities in Hubei should set up a reasonable teaching plan according to the specific circumstances of teaching. In accordance with the whole university's learning setting course, a clear learning plan [9] is established in each semester. The cultivation of e-commerce talents in rural areas should broaden the channels, be in line with other professional training methods, and be 
upgraded to key or strategic majors in schools. E-commerce talents in rural areas must have a good understanding of agricultural products, increase the opportunities to enter enterprise practice, and provide more opportunities for rural and peasant contacts, such as collective study in Jingdong and other e-commerce companies, visit farms and plantations in rural Hubei Province. The government regularly dispatches teams of experts to schools and rural areas to explain and publicize the government's real-time policies in developing rural e-commerce. The government funded the establishment of rural e-commerce training courses for young people intending to engage in e-commerce undertakings in rural areas, will be engaged in e-commerce experienced experts invited to rural areas, the local people for one-on-one training, explain e-commerce knowledge.

\subsubsection{Pay attention to the integration of agricultural knowledge}

Universities should pay attention to the integration of agricultural knowledge and relevant courses in agriculture. Pay attention to explaining the knowledge of agricultural products, such as common knowledge of the type and growth cycle of agricultural products. Focus on the integration of agricultural products and e-commerce, because the preservation time of agricultural products is greatly limited, the logistics distribution of time and freshness requirements are particularly high, so teaching should start from the characteristics of agricultural products, can not be partial generalization [10].

\subsubsection{Providing practical teaching links}

Training practical talents is the strategic requirement of Hubei government in recent years. Colleges and universities in Hubei province should pay attention to the construction of teaching practice base to provide more convenience and conditions for practical talents. In the construction of training base, we should focus on two aspects. On the one hand, enter the e-commerce enterprises to learn the knowledge of agricultural products e-commerce, and build a school-enterprise cooperation base; on the other hand, we should go deep into the rural grass-roots level and the peasants to learn and exchange, and experience the production conditions of agricultural products. Agricultural infrastructure such as farmland can be built to provide more practical opportunities for agricultural teaching.

\subsubsection{Strengthening the construction of teaching staff}

Only a comprehensive team of teachers can cultivate comprehensive e-commerce talents in rural areas. According to the actual situation of rural e-commerce development in Hubei, a professional team of teachers is set up. Teachers team need to integrate and strengthen, organize school teachers to visit agricultural production base regularly, to e-commerce enterprises to exchange and learn. In the design of teachers, we should make reasonable plans, coordinate the proportion of middle-aged teachers and old teachers, distribute the agricultural products teachers and e-commerce teachers evenly, and make appropriate proportion of teachers between men and women [11].

\subsection{Increase support}

\subsubsection{Perfect the policy}

The Hubei provincial government should perfect the policy of rural e-commerce and build a demonstration base of rural e-commerce through policy planning. The introduction of start-up companies to reduce and exempt e-commerce companies in rural areas of Hubei Province from taxation, providing considerable social security and welfare benefits. Let the masses understand and learn the sustainable development benefits brought by the electricity supplier, and embrace the electricity supplier.

\subsubsection{Increase investment}

The Hubei provincial government should guarantee the reasonable capital input, apply for more needed funds for the development of rural e-commerce, introduce more people into rural e-commerce, 
promote e-commerce into rural demonstration work, give full play to the leadership role of the Hubei provincial government, and guide more social capital to invest in the construction of rural e-commerce in Hubei province. Set up a team, so as to promote the influx of talent. Schools should also devote part of their funds to the practice of E-commerce Teaching in rural areas, cooperate with enterprises and producers of agricultural products, and attract foreign funds by utilizing the school's student resources, such as the use of targeted talent training for rural e-commerce enterprises, advertising and other methods to collect fees.

\subsubsection{Strengthening infrastructure construction}

Establish agricultural information network infrastructure, establish Hubei agricultural products information website, regularly release agricultural products knowledge and real-time dynamic of e-commerce. The existing network information platform docking, so that more people through the network way to understand agricultural e-commerce, stimulate their interest in the development of rural e-commerce. In the interview with Jingdong Mall, they think that the most stringent requirement of fresh products is the time limit of distribution. It is very important to build an efficient logistics system, build logistics channels and establish distribution sites.

\subsubsection{Create a good atmosphere}

To create a good e-commerce atmosphere in the vast rural areas of Hubei Province, the government can set up a local E-Commerce Association in Hubei Province, aiming at the exchange and development of rural e-commerce, guiding the rational and healthy development of e-commerce. At the same time, the Hubei provincial government needs to help the introduction of professional teachers into the association, the association members to implement professional, accurate propaganda. The association can use the resources of the government, enterprises, universities and rural areas to disseminate e-commerce knowledge in rural areas [12].

\subsection{Innovative training mode}

\subsection{1 "Order form" training}

Local governments in Hubei Province can sign strategic cooperation with universities, colleges and universities can formulate professional personnel training according to the number of rural e-commerce talents required by local governments, sign agreements with interested students, and local governments can provide considerable returns and give these talents to local employment after graduation. At the same time, local governments can lead students to practice and study at that time from time to time, so as to ensure the quality of talent and meet the local government's demand for talent and students' own employment intention

\subsubsection{Localization training}

The establishment of e-commerce online schools in rural areas of Hubei Province provides free online teaching resources and encourages rural people to actively register. At the same time, targeted training for rural people will be carried out to develop e-commerce service network in rural areas. Network teaching should provide diversified courses so that more farmers can understand the general trend of the Internet and realize the optimistic benefits of E-commercialization of agricultural products. Fully integrate the resources of poverty alleviation institutions, universities and other parties, so that all sectors of society and the rural masses are connected, thus promoting the development of local e-commerce. 


\subsection{3 "Crowd raising" training}

Local governments in Hubei can raise funds from the public, publicize the social benefits that e-commerce development can bring to the countryside, and encourage and attract investment from all walks of life. For example, in cooperation with enterprises, enterprises provide funds for the construction of rural e-commerce infrastructure, and agricultural producers offer preferential treatment for these enterprises when introducing agricultural products. The government uses public funds to strengthen network promotion, information construction and infrastructure construction, and promote the construction and development of e-commerce in rural areas.

\section{Conclusion}

At present, there are many problems in the training mode of rural e-commerce talents in Hubei. The cultivation of rural e-commerce talents requires the Hubei provincial government to increase policy support and strengthen infrastructure construction. In the process of training rural e-commerce talents, we should consider and improve the training ability and support. Rational planning and training programs, focusing on the integration of agricultural knowledge, providing practical teaching links and strengthening the construction of teachers; from the point of view of enhancing support, we should improve policies, increase investment, strengthen infrastructure construction and create a good atmosphere. At the same time, we can also use the "order-based" training, the "localization" training, the "crowd sourcing" training and other innovative training mode.

\section{Acknowledgements}

This work was supported by the grants from Hubei Provincial Collaborative Innovation Centre of Agricultural E-Commerce (Wuhan Donghu university research [2016] No. 15Document).

\section{References}

[1] Sun Wei. The Training Mode of E-commerce Talents in Applied Higher Vocational Colleges: From the Perspective of Serving "Agriculture, Countryside and Agriculture" [J]. North Economy and Trade,2013(02):34-43.

[2] Cheng Lili. Research on the Training Way of Rural E-commerce Applied Talents with "Multidimensional Nested" Mode under the Information Technology Environment[J]. China's Education Informatization,2014(16):47-49.

[3] Lai Lingling, He Xiaofeng. Analysis of personnel training in rural e-commerce development [J]. logistics engineering and management, 2016,38(12):173-175.

[4] Ji Yuan. The training mode of applied talents for rural e-commerce in local colleges and universities [J]. Jiangsu agricultural science, 2016,44(10):576-578.

[5] Ren Xiaocong, He Jun. The development trend, problems and Countermeasures of rural e-commerce in China, and the discussion of modern economy, 2017,03

[6] Wang Hui. Short board construction of rural e-commerce development in North Guangdong: take Shaoguan as an example, [J]. farmer's staff.2017(14):200-201.

[7] Qiu Leiming, Tong Hongbin. Research on the Training Model of Rural E-commerce Talents in Higher Vocational Colleges [J]. Journal of Taiyuan City Vocational and Technical College, 2016 (02):112-115.

[8] Wang Wei. Exploration on the systematic training of e-commerce skilled personnel [J]. Journal of Shandong Agricultural Engineering College,2014,31(03):175-176.

[9] Ludan. An Analysis of the Relocation Path of Rural Surplus Labor Force from the Perspective of 
Rural E-commerce Development [J]. Agricultural Economic Issues, 2015,36(03):62-68.

[10] Jingfeng Z. On the Training Path of Compound Talents for E-Business in China[J]. Advances in Information Technology and Education, 2011(14):15-16.

[11] Wu Guoming, Tan Yanhua. Current situation, problems and Countermeasures of rural e-commerce talents development [J]. E-commerce, 2017(05):62-64.

[12] Li Zhu. Reflections on the training of e-commerce talents in new rural areas of Vocational Colleges [J]. cooperative economy and technology, 2012 (24):100-101. 